NBER WORKING PAPER SERIES

\title{
IMPLICATIONS OF THE COVID-19 PANDEMIC FOR STATE GOVERNMENT TAX REVENUES
}

\author{
Jeffrey Clemens \\ Stan Veuger \\ Working Paper 27426 \\ http://www.nber.org/papers/w27426 \\ NATIONAL BUREAU OF ECONOMIC RESEARCH \\ 1050 Massachusetts Avenue \\ Cambridge, MA 02138 \\ June 2020
}

We thank Philip Hoxie for excellent research assistance. We thank Daniel Shoag and Naomi Feldman for comments. The views expressed herein are those of the authors and do not necessarily reflect the views of the National Bureau of Economic Research.

NBER working papers are circulated for discussion and comment purposes. They have not been peer-reviewed or been subject to the review by the NBER Board of Directors that accompanies official NBER publications.

(C) 2020 by Jeffrey Clemens and Stan Veuger. All rights reserved. Short sections of text, not to exceed two paragraphs, may be quoted without explicit permission provided that full credit, including $\odot$ notice, is given to the source. 
Implications of the Covid-19 Pandemic for State Government Tax Revenues

Jeffrey Clemens and Stan Veuger

NBER Working Paper No. 27426

June 2020

JEL No. H10,H12,H71,H79

\begin{abstract}
$\underline{\text { ABSTRACT }}$
We assess the Covid-19 pandemic's implications for state government sales and income tax revenues. We estimate that the economic declines implied by recent forecasts from the Congressional Budget Office will lead to a shortfall of roughly $\$ 106$ billion in states' sales and income tax revenues for the 2021 fiscal year. This is equivalent to 0.5 percent of GDP and 11.5 percent of our pre-Covid sales and income tax projection. Additional tax shortfalls from the second quarter of 2020 may amount to roughly $\$ 42$ billion. We discuss how these revenue declines fit into several pieces of the broader economic context. These include other revenues (e.g., university tuition and fees) that are also at risk, as well as assets (e.g., pension plan holdings) that are at risk. Further dimensions of context include support enacted through several pieces of federal legislation, as well as spending needs necessitated by the public health crisis itself.
\end{abstract}

Jeffrey Clemens

Department of Economics

University of California, San Diego

9500 Gilman Drive \#0508

La Jolla, CA 92093

and NBER

jeffclemens@ucsd.edu

Stan Veuger

American Enterprise Institute

stan.veuger@aei.org 


\section{INTRODUCTION}

During economic downturns, the budgets of state and local governments come under stress. Stress arises due to contractions in revenues and increases in expenditure needs. While the same is broadly true of federal, state, and local governments alike, the U.S. federal government is empowered to issue both short- and long-term general obligation debt. State and local governments, by contrast, have restrictions of varying degrees of severity on their legal authority to issue debt in response to unexpected spending or revenue shocks (Poterba, 1994; Clemens and Miran, 2012; Driessen, 2020). Local governments also face legal, in addition to economic, limits on their ability to raise tax rates (Shoag, Tuttle, and Veuger, 2019). Together, these constraints place downward pressure on expenditures during downturns, precisely when many expenditures are most valuable. Our purpose in this paper is to provide an initial look at the shocks to state governments' revenue streams during the initial months of the Covid-19 pandemic.

Broadly speaking, the size of states' revenue contractions can be analyzed through the lens of three factors. The first factor is the severity of the Covid-19 crisis per se. The second is the sensitivity of states' revenue bases to the crisis. The third is the sensitivity of states' revenues to their revenue bases. Put differently, the first factor involves the rise in health risks and associated declines in employment and consumption, the second maps these declines into states' revenue bases, and the third maps revenue bases into revenues.

We compare the pandemic's likely impact on state governments' revenues to more typical economic contractions. Unlike typical contractions, during which income declines more dramatically than consumption (Canova, 1998), the Covid-19 lockdowns generated unusually large declines in consumption relative to income. This is in no small part because incomes have been buoyed by fiscal stimulus, some of which is taxable and some of which is not. Further, Covid-19 has resulted in a dramatic 
decline in personal consumption expenditures on health care, restaurants, and lodgings. Short-run revenue strains were thus particularly severe in states that rely to a significant degree on sales taxes, and in particular on sales in exposed industries. As in most recessions, property tax bases are unlikely to contract significantly during the downturn itself because property values are typically reassessed with substantial lags (Lutz, Molloy, and Shan, 2011).

Our discussion and analysis proceed as follows. In section 2 we answer the question: on what tax bases do states and localities tend to rely and how do those tax bases vary across states? In section 3 we tackle multiple issues. We first present health and macroeconomic data that describe the magnitude of the Covid-19 shock during its initial months. Next, we analyze how the pandemic has altered economics forecasts produced by the Congressional Budget Office. We then assess what these forecast revisions imply for state revenues. This analysis draws on existing research on the responsiveness of revenue to changes in economic activity. The focus of section 4 is the broader institutional environment of state-level balanced-budget rules and rainy-day funds. Section 5 discusses the federal government, including an overview of federal relief for state and local governments that has been enacted during the downturn's early stages. Section 6 concludes with a discussion of additional issues related to the design of the American system of fiscal federalism.

\section{STATE AND LOCAL GOVERNMENT REVENUE STREAMS}

In our analysis of state and local governments' revenue streams, we begin by presenting data on the breakdown of each state's revenues across major revenue bases. Table 1 provides summary statistics for localities as well as for states. While states will be the main focus of our analysis, we present data for localities for purposes of contrast and illustration. In a similarly motivated discussion, 
Dye (2004) presents a similar set of statistics and descriptions of state governments' tax bases at the time of the 2001 U.S. recession.

Table 1 shows that states' degrees of reliance on different revenue streams varies widely. State governments' reliance on sales and gross-receipt taxes (both "general" and "selective") varies from $20.5 \%$ of own-source general revenues in the $10^{\text {th }}$ percentile state to $55.3 \%$ at the $90^{\text {th }}$ percentile. Local governments' reliance on sales taxes is dramatically lower; it varies from $0.7 \%$ of own-source general revenues at the $10^{\text {th }}$ percentile to $22.5 \%$ at the $90^{\text {th }}$. Income taxes are another important source of revenue for some states; the $90^{\text {th }}$ percentile state raises nearly $40 \%$ of its own-source general revenue from personal income taxes. A relatively small number of local governments assess taxes on personal income at all. Property taxes follow a dramatically different pattern: the $90^{\text {th }}$-percentile state relies on property taxes less heavily (only $7.0 \%$ of own-source general revenues) than do the local governments in the $10^{\text {th }}$-percentile state (33.0\% of own-source general revenues).

A large share of states' own-source revenues falls outside of the conventional sales, income, and property tax bases. The Census Bureau labels these sources "Charges and Miscellaneous General Revenue." Under this heading, the largest well-specified category involves tuition and fees for public institutions of higher learning. The second largest involves payments to hospitals. Shortfalls in these fees (or "user fees") will tend to be borne by the associated hospitals and institutions of higher education. This differentiates these sources of revenue from sales and income taxes, which are less commonly earmarked to specific agencies or institutions. The Census Bureau categorizes roughly $10 \%$ of states' own-source general revenues as either "Current Charges: Other Charges" or "Miscellaneous General Revenue: Other General Revenue." While these headings are not particularly informative, they reflect the substantial variation in states' non-tax revenue instruments. 
Columns 6 and 7 of Table 1 provide perspective on how the revenue raising of state and local governments relates to the size of the overall economy. Aggregated to the national level, states raised roughly $\$ 1.3$ trillion in own-source general revenues in 2017 , while localities raised roughly $\$ 1.1$ trillion. Combined, these revenues were equivalent to just over $12 \%$ of U.S. GDP. The state sales and income tax revenues on which we focus are equivalent to just over $4 \%$ of GDP. Both the absolute and relative size of state governments, as well as their degree of reliance on sales and income taxes, are substantially greater than several decades ago (Baicker, Clemens, and Singhal, 2012).

\section{THE COVID-19 SHOCK TO STATE GOVERNMENT TAX REVENUES}

Covid-19 has impacted the economies of all 50 states on a substantial scale (Bureau of Labor Statistics, 2020a; Bureau of Economic Analysis, 2020). Through early June, the pandemic has been felt more intensely in the Northeast than in other regions. ${ }^{2}$ Nonetheless, through June 9 th there had been more than 1 recorded case per 1,000 residents in all states but Alaska, Hawaii, and Montana (Smith et al., 2020). While the severity of the public health crisis has varied substantially across states, effects on states' labor markets and economic output have all been quite dramatic.

This section proceeds in four parts. First, we present data on Covid-19's immediate and projected impacts on economic activity. Second, we discuss key aspects of states' tax bases that are relevant for mapping changes in economic activity into changes in revenues. Third, we present our estimates of Covid-19's recent and impending impact on state government sales and income tax revenues. Fourth, we discuss key factors our calculations leave out, as well as sources of uncertainty.

\footnotetext{
${ }^{2}$ Covid-19 deaths have been disproportionately concentrated in the Northeast, which accounts 60 percent of deaths and just 17 percent of the US population (Smith et al., 2020).
} 


\section{A. COVID-19'S EFFECTS ON ECONOMIC ACTIVITY}

Table 2 presents national data on the magnitude of shocks associated with Covid-19. At the time of our writing, employment data were available through May, while data on personal income and consumption expenditures were available through April. Through April, the number of employed persons was down by roughly $13 \%$ relative to its level from the previous year. The corresponding rise in the unemployment rate was roughly 11 percentage points, with a slight recovery in May. Also through April, wage and salary income had declined by just over $8 \%$ relative to a year before. Across the available metrics, contractions were historically unprecedented in April, following a significant worsening in the economic environment in March.

Aggregate consumption expenditures declined by roughly 17\% from April 2019 to April 2020. While consumption declines were similar, in aggregate, for goods and services, there was considerable variation across each aggregate's sub-categories. Spending on food from restaurants, for example, fell roughly in half from April 2019 to April 2020. Spending on groceries rose significantly in March, then reverted to trend. Spending on health care and durable goods both declined substantially, while spending on professional services outside of health care (e.g., legal and financial services) was relatively stable.

How will shocks from Covid-19 translate into shocks to state government revenues? This question can be usefully divided into two components, both of which require careful consideration. The first question is how Covid-19 will affect future economic activity, which in turn determines the size of states' tax bases. As detailed below, we answer this question using May 2020 forecasts from the

Congressional Budget Office. The second question is how changes in states' tax bases will translate into 
changes in revenues. On this point, as also explained below, we draw on a combination of pandemicspecific insights and past research on the relationship between revenues and tax bases.

Estimates of changes in tax bases are the key source of uncertainty faced by efforts to forecast revenue declines during downturns. We set out to quantify two tax shortfalls. The first is the shortfall that emerged in the last quarter of most states' 2020 fiscal years. The second is the tax shortfall states will likely encounter in the 2021 fiscal year, which begins on July 1, 2020, for the vast majority of states. Conveniently for this purpose, the Congressional Budget Office (CBO) released a 10-year economic outlook in January (Congressional Budget Office, 2020a), then revised that outlook in May (Congressional Budget Office, 2020b). The January 2020 forecast predated meaningful Covid-19 concerns as they pertained to forecasts for the U.S. economy. The May revision incorporated CBO's assessment of the Covid-19 pandemic's potential effects on the economy.

Figures 1 and 2 present key projections from CBO's January and May reports for the first quarter of 2019 through the fourth quarter of 2021. Figure 1 presents CBO's forecast for nominal GDP. As in CBO's reports, quarterly values are expressed on an annualized basis. That is, the $\$ 21$ trillion level of GDP in the first quarter of 2019 reflects a year's worth of GDP if the economy were to remain fixed in size. The decline in GDP from the fourth quarter of 2019 to the first quarter of 2020 reflects data that have been collected and largely finalized by the relevant statistical agencies. At the time of our writing, as well as the time of CBO's report, values for the second quarter of 2020 were forecasts based on data available through May. Values for subsequent quarters are entirely forecast-driven. As of May, CBO forecast a substantial decline in GDP from the first to the second quarter of 2020, followed by a resumption of growth from levels that are depressed substantially relative to prior forecasts.

Figure 2 presents time series that connect more directly to our revenue estimates along two dimensions. The first dimension involves the underlying series. Rather than GDP, Figure 2 presents data 
on aggregate personal income and aggregate personal consumption expenditures. These aggregates are relevant for thinking about shocks to states' personal income and sales tax bases, respectively. Second, we normalize (or "index") each series relative to its value for the fourth quarter of 2019. This makes it easier to visually translate changes in each series into percent terms.

Two details of the series presented in Figure 2 have high relevance for assessing Covid-19's effects on state government revenues. First, public health measures including stay-at-home-orders and the closure of restaurants, retail outlets, and other businesses contributed to a substantial decline in consumption relative to income. Consumption for the second quarter is forecast to decline roughly $10 \%$ more than income, which is unusual relative to typical recessionary patterns. ${ }^{3}$ Second, both the income and consumption series were projected to "stabilize" at levels roughly 8 to $9 \%$ below their January forecast values for the quarters associated with states' 2021 fiscal years. Percent differences in the January and May forecasts for these macroeconomic aggregates are the primary input into our estimates of Covid-19's effects on states' tax bases.

Figure 3 below presents comparable, indexed series on income and consumption for the period associated with the Great Recession. The key difference between the pandemic and Great Recession is that consumption evolved more smoothly during the Great Recession, as has historically been the case during economic downturns. The pandemic's effect on the economy, by contrast, is associated with an unusually sharp decline in consumption, which non-trivially exceeds the expected decline in income. Consequently, sales tax revenues will suffer far greater losses, relative to income tax revenues, during the second quarter of calendar year 2020 than they would at the beginning of a typical recession. ${ }^{4}$

\footnotetext{
${ }^{3}$ Strikingly, personal income data for the month of April revealed that the Economic Impact Payments and expanded unemployment insurance benefits enacted through the CARES Act were sufficiently large that aggregate income rose even as output and consumption declined dramatically (Bureau of Economic Analysis, 2020). ${ }^{4}$ Note, however, that the timing of income tax receipts is highly uncertain due to changes in federal and state filing deadlines.
} 


\section{B. TRANSLATING ECONOMIC SHOCKS INTO CHANGES IN STATE GOVERNMENT REVENUES}

How will shocks to economic activity translate into shocks to state government revenues? To answer this question, we combine three sets of information. The first is information on the magnitude and composition of macroeconomic shocks, as presented in the previous section. The second is information on key institutional characteristics of state governments' tax bases. The third consists of the research literature's evidence on the historical sensitivity of tax revenues to economic shocks.

The economic aggregates presented in the previous section are proxies for state governments' income and sales tax bases. They are imperfect proxies, however, since some sales and some forms of income are untaxed, while some sales and forms of income and are taxed at different rates than others. In our calculations, for example, we account for the fact that the Economic Impact Payments included in the March 2020 CARES Act legislation are not taxable, while expanded unemployment insurance benefits, in contrast, are taxable. States' income tax bases exhibit more uniformity than sales tax bases, due in large part to states' tendency to conform their income tax bases to the federal income tax base. ${ }^{5}$

The relationship between personal income tax revenues and changes in the size of the applicable tax base depends on the degree of the tax structure's progressivity. Progressive tax bases will, in general, have revenue elasticities in excess of one. This reflects the fact that the average applicable rate will tend to decline as the tax base contracts. Research on elasticities of tax revenues with respect to tax bases has long been consistent with this intuition. ${ }^{6}$ Our reading of the literature leads us to

\footnotetext{
${ }^{5}$ As summarized in a report disseminated by the Tax Foundation (Walczak, 2018), among the states with some form of personal income tax, the vast majority conform in key respects to the federal income tax base. Walczak (2018) codes only 5 states as starting from bases other than the federal income tax base. Among the others, roughly half maintain conformity with the federal income tax on a rolling basis, while the other half conform to a static (though occasionally updated) historical version of the federal income tax code.

${ }^{6}$ See, for example, papers by Holcombe and Sobel (1997), by Bruce, Fox, and Tuttle (2006), by Reed, Rogers, and Skidmore (2011), by Dye (2004), by Anderson and Shimul (2018), and by Hawkins (2000). Recent papers by Seegert
} 
assume that the average state's personal income tax revenues will decline by roughly 1.6 percent for each one percent decline in personal income. This elasticity draws most directly on estimates from Holcombe and Sobel (1997), Kodrzycki (2014), and Anderson and Shimul (2018). Note that our income tax shortfall estimates would shift proportionally with changes in this assumed elasticity.

State sales tax bases exhibit far more variation than their income tax bases. For a recent overview of state sales tax bases and rates, we refer readers to Walczak (2019). Translating changes in aggregate consumption into changes in states' sales tax bases is challenging due to variations in states' exemptions. A limitation is that exemption categories do not translate seamlessly into consumption categories tracked by the Bureau of Economic Analysis. Some relevant patterns are clear, however. Legal, financial, and accounting services are exempt from sales taxation in the vast majority of states, for example, as are groceries (Walczak, 2019). Hence most states' sales tax bases exempt some of the more resilient consumption categories over the early stages of the Covid-19 pandemic. At the same time, medical care is also exempt in the vast majority of states, meaning states' tax bases exclude a large category that has experienced disproportionately large consumption declines. A key lesson is that states' tax bases are far narrower than consumption as an economic aggregate, making it difficult to work backwards on the basis of exemptions. Kaeding (2017), for example, reports that state sales tax bases in 2017 were equivalent to roughly $23 \%$ of personal income.

Mechanically, flat-rate sales tax revenues will fluctuate proportionally with changes in the sales tax base. Because consumption declines appear, in aggregate, to be moderately more concentrated among taxed (vs. exempt) categories of consumption, we assume that each 1 percent change in the aggregate consumption base generates a 1.1 percent change in sales tax revenues. There are two key

(2016) and Kodrzycki (2014) document that the cyclical sensitivity of states' revenues has increased over time. Clemens (2012) shows that states' expenditures exhibit greater sensitivity to changes in aggregate income when their revenues rely to a greater degree on relatively volatile tax bases, as would be expected in light of their balanced budget requirements. 
caveats to the resulting calculations. First, there is uncertainty about the appropriate adjustment for projecting total sales tax collections around the country. Second, our calculation will explicitly fail to capture variations driven by differences in exemptions across states.

\section{C. THE COVID-19 SHOCK TO STATE AND LOCAL GOVERNMENT REVENUES}

In this section we present our estimates of the Covid-19 pandemic's effect on state government tax revenues. To facilitate comparisons across states, the revenue figures that form the basis of our calculations come from the Annual Survey of State and Local Government Finances. The Census Bureau goes to great effort to harmonize broad revenue categories across states, which is useful for our purposes. A key caveat, of course, is that the harmonized figures may clash with what one might expect based on an inspection of a given state's budget documents. At the time of our writing, 2017 was the last year for which the Census Bureau had harmonized and reported state government finance data (United States Census Bureau, 2019).

We compute two distinct shortfall estimates. The first is a shortfall for the second quarter of 2020, which corresponds to the final quarter of the 2020 fiscal year for the vast majority of states. The second is a shortfall for the third quarter of 2020 through the second quarter of 2021, which corresponds to the 2021 fiscal year for the vast majority of states.

We calculate the shortfall (Revenue Shortfall $i, b$ ) for state $i$ from tax base $b$ as follows:

$$
\text { Revenue Shortfall }_{i, b}=\text { Counterfactual Revenue }_{i, b} \times \text { Base Decline }_{b} \times \text { Revenue Elasticity }_{b} \text {. }
$$

In the expression above, Counterfactual Revenue Re $_{i}$ is the estimated revenue from tax base $b$ for state $i$ in the absence of the COVID-19 pandemic. We obtain these estimates by straightforwardly projecting forward the Census Bureau's most recent estimates. Since these estimates are of 2017 revenue collections, we account for three years of nominal revenue growth by multiplying the 2017 
values by one plus each state's nominal GDP growth from the fourth quarter of 2016 to the fourth quarter of 2019. The Base Decline ${ }_{b}$ term corresponds to our estimate of the Covid 19-induced decline in either the income or sales tax base, as described in Section III A. We express Base Decline $_{b}$ in percent terms. Finally, Revenue Elasticity Els $_{b}$ an estimate of the elasticity of revenues with respect to size of the tax base, as described in Section III B. The product of the percent decline in the base $\left({\left.\text { Base } \text { Decline }_{b}\right) \text { and the elasticity (Revenue Elasticity }}_{b}\right.$ ) yields an estimated percent shortfall in revenues. Multiplying this percent shortfall by counterfactual revenues (Counterfactual Revenue ${ }_{i, b}$ ) yields shortfalls expressed in dollar terms (Revenue Shortfall ${ }_{i, b}$ ).

Table 3 presents the shortfalls we estimate at the national level. The estimated shortfalls appear in Panel B and the underlying inputs, which are described in detail in the previous section, appear in Panel A. In aggregate across the country, we estimate that the Covid-19 pandemic will reduce states' tax collections by $\$ 42$ billion in the second quarter of 2020 , with $\$ 23$ billion coming from reduced sales tax collections and $\$ 19$ billion coming from reduced income tax collections. ${ }^{7}$ This reflects the relative size of typical sales and income tax collections as well as the severity of the second quarter shock to consumption relative to income. For the year extending from the third quarter of 2020 through the second quarter of 2021, we estimate that states' sales and income tax revenues will fall roughly \$106 billion short of what one would have projected in January. Over the coming fiscal year, the average revenue decline per quarter is $\$ 27$ billion. This is substantially less than our shortfall estimate for the second quarter of 2020 , reflecting the severity of the short-run downturn as projected by CBO. The decline for fiscal year 2021 comes to a moderately greater degree from income taxes relative to sales

\footnotetext{
${ }^{7}$ Note that actual income tax collections in the second quarter of 2020 may be dramatically lower due to pandemic-driven changes in states' filing deadlines. Our estimates are meant to capture shortfalls that would remain in the absence of any timing effects associated with states' filing deadlines.
} 
taxes. This reflects the convergence of CBO's forecasts for personal income and personal consumption expenditures as the forecast shifts from the second quarter of 2020 into later quarters.

We next consider variations in exposure to revenue declines across states. Broadly speaking, variations in exposure to sales and income tax declines reflect two factors we can capture in our calculations. The first is the fact that a larger fraction of some states' revenues come from these sources rather than other sources. The second is the fact that some states' total revenues are greater than others, such that a given percent decline generates a greater absolute decline. To make large and small states comparable, we begin by converting their revenue figures into per capita terms. As before, we inflate 2017 values to account for three years of growth. We present the resulting counterfactual projections of states' per capita sales plus income tax revenues in Figure 4. There is substantial variation, with the $90^{\text {th }}$ percentile state collecting just under $\$ 4,000$ in combined sales and income tax revenue per capita and the $10^{\text {th }}$ percentile state collecting just under $\$ 1,900$ in such revenues per capita. The $90^{\text {th }}$ and $10^{\text {th }}$ percentile states thus differ by a factor of 2 .

Table 4 presents state-level variations in the per capita revenue shocks we estimate. The mean of the projected revenue shortfalls we estimate for sales and income taxes combined are $\$ 119$ per capita for the second quarter of 2020 and $\$ 303$ per capita for the subsequent fiscal year. In per capita terms, these numbers may sound modest. It is thus important to keep in mind that they extrapolate to the aggregate declines of $\$ 42$ billion and $\$ 106$ billion presented in Table 3. The revenue shortfalls we estimate for the 2021 fiscal year exhibit substantial variation across states. This largely reflects two facts: income is a volatile revenue source and states' reliance on personal income taxation varies quite extensively across states. States that do not collect personal income taxes tend to be states with relatively small projected shortfalls per capita. Notable examples include Florida and Texas. 


\section{D. CAVEATS FOR INTERPRETING OUR CALCULATION}

It is important to be clear regarding sources of uncertainty underlying our calculations. In this section, we discuss sources of uncertainty along with an overview of what our calculations are intended to capture and what they leave out. Two initial factors involve the pandemic's economic effects. If the CBO's May 2020 forecast turns out to be overly optimistic, for example, then our calculations will tend to understate shortfalls to states' sales and income tax revenues. Further, the pandemic's course may differ significantly across states. Our estimates do not attempt to account for cross-state variations in the pandemic's severity, either to date or in expectation. ${ }^{8}$ Through May, for example, the count of employed persons in New York was down by substantially more (18.3 percent) relative to May 2019 than employment in relatively lightly hit Montana (down 8.6 percent). ${ }^{9}$

Additional factors relate specifically to our sales tax estimates. Our mapping of CBO's forecast for consumption expenditures into sales tax bases may either over or understate changes in statespecific sales tax bases. This mapping can impact both our aggregate figures and the variations we estimate across states. Hawaii, New Mexico, and South Dakota, for example, are unusual in their taxation of professional services, for which consumption has been stable (Walczak, 2019). These states' sales tax revenues may thus be more resilient than other states' sales tax revenues. Nevada, by contrast, has tax revenues connected to its extensive leisure and hospitality sector, and may thus have a less resilient sales tax base than the typical state.

Further factors relate to our income tax estimates. The elasticity we apply to CBO's forecast for personal income may either over or understate states' exposure to declines in income tax revenues. On

\footnotetext{
${ }^{8}$ In addition to fluctuations in revenue streams, economic downturns can affect states' fiscal positions through changes in asset prices. In particular, state pension asset holdings are large enough that disappointing investment returns can cause shortfalls of substantial size (Farrell et al., forthcoming). Asset prices fluctuated wildly over the first half of 2020, and their future path will have important implications for state budgets through this channel. ${ }^{9}$ Both figures come from the June release of the "State Employment and Unemployment Summary" for May, which are subject to revision in subsequent months (Bureau of Labor Statistics, 2020b).
} 
the one hand, states' income tax revenues have become more volatile over time (Seegert, 2016). Historical estimates of revenue elasticities may thus understate what we should presently project. All else equal, the nine states with flat-rate income taxes may tend to experience smaller declines in revenue than those with progressive structures (Loughead, 2020). ${ }^{10}$ On the other hand, lost jobs have been concentrated disproportionately in relatively low-income retail and food service industries. In this environment, income tax progressivity may lead aggregate income tax revenues to decline less dramatically than one would predict if incomes were to fall proportionally across the distribution.

Finally, the pandemic will affect states' revenue sources other than income and sales taxes. As shown in Table 1, substantial state revenues come through miscellaneous charges and fees. Minor sources of fees include tolls, airport charges, and parks. Several states derive significant amounts of revenue from various sources related to the extraction of natural resources. These states may experience substantial declines in revenue due to declines in commodity prices. Publicly run hospitals are a substantial source of fees that, paradoxically, have likely declined during the pandemic due to significant declines in overall healthcare consumption. The single largest source of charges and fees is higher education. We now present more detail on tuition charges and other higher education fees.

The map in Figure 5 displays variations in states' exposure to declines in tuition and fees. The Covid-19 pandemic subjects tuition and fee revenues to far greater uncertainty than typical recessions. Substantial declines may come from several sources. First, non-residential learning models reduce revenues through residential and dining fees. Second, the pandemic may depress total enrollments, and thus total tuition revenues. Third, the pandemic may shift enrollments towards in-state students and away from out-of-state students (both international and domestic). This compositional change has the

\footnotetext{
${ }^{10}$ As enumerated by Loughead (2020), the 9 states with flat-rate (or single-rate) income tax systems are Colorado, Kentucky, Illinois, Indiana, Massachusetts, North Carolina, Pennsylvania, Tennessee, and Utah. Loughead (2020) reports that New Hampshire has a flat-rate system that applies exclusively to interest and dividend income.
} 
potential to reduce tuition revenues substantially. States vary considerably in their exposure to declines in tuition and fees. Exposure at the $10^{\text {th }}$ percentile amounts to moderately under $\$ 300$ per capita (roughly $6.5 \%$ of the average state's total own-source revenues), while exposure at the $90^{\text {th }}$ percentile amounts to moderately over $\$ 600$ per capita (roughly $13 \%$ of the average state's total own-source revenues).

\section{THE INSTITUTIONAL ENVIRONMENT}

The revenue shortfalls discussed in the previous section are a key input for decisions regarding the allocation of resources to the states by the federal government. Two additional factors deserve attention before we turn to the initial wave of federal legislation enacted in response to the pandemic. First, 49 of 50 states face a constitutional or statutory balanced-budget requirement of some kind, which constrains their ability to respond to economic downturns. At the same time, states can accumulate rainy-day funds that allow them some flexibility as they adjust to depressed revenues.

States' balanced-budget requirements come in a variety of different forms. Key differences across states involves factors like whether the governor must submit a balanced budget; whether the legislature must pass a balanced budget; and whether the state may realize and carry over deficits that arise due to unanticipated shocks. Around 40 states have adopted each of these provisions and Vermont is the only state lacking all three types of requirements (National Conference of State Legislatures, 2010). Research has shown that limitations on the ability to carry unexpected deficits across fiscal years have empirically important effects on the pace at which states cut spending or raise taxes following unexpected, mid-year shocks (Poterba, 1994; Clemens and Miran, 2012). ${ }^{11}$ These rules may thus be

\footnotetext{
${ }^{11}$ Specifically, Poterba (1994) and Clemens and Miran (2012) find that states with strong requirements enact budget cuts that are three times greater than the cuts implemented by states with weak restrictions per dollar of unexpected deficit.
} 
quite relevant for states' short-run responses to the revenue shocks they have experienced during the second quarter of 2020. Because this was the last quarter of most states' fiscal years, restrictions on carrying over deficits will, at least in principle, require prompt action.

While balanced-budget requirements impose restrictions on states' fiscal-policy options, rainyday funds provide some flexibility (Zhao, 2016). Totaled across the country, states' rainy-day fund balances have reached $\$ 70$ billion in recent years (National Association of State Budget Officers, 2019). Two factors complicate states' ability to offset Covid-19's budgetary fallout through rainy day funds (National Conference of State Legislatures, 2018). First, in part because some states face caps on the reserves they can accumulate, their rainy-day funds are unlikely to be sufficient to offset pandemicinduced revenue shortfalls. Table 5 shows that states' rainy-day funds can typically cover less than $10 \%$ of annual expenditures. In several of the largest states, the funds are substantially smaller. Second, there are restrictions on how funds can be accessed and when they must be paid back. A few examples may be helpful to illustrate these restrictions. Colorado's fund can only be used to address revenue shortfalls triggered by natural disasters (Tax Policy Center, 2018). lowa and Rhode Island require repayment by the end of the next fiscal year (The Pew Charitable Trusts, 2017). Withdrawals overwhelmingly require the legislative branch's stamp of approval; in Hawaii, for example, they require a two-thirds majority in both legislative chambers (Department of Budget and Finance, State of Hawaii, 2020).

\section{THE FEDERAL GOVERNMENT}

The federal government has responded to the Covid-19 pandemic and the concomitant economic crisis by passing a number of pieces of emergency legislation. In addition and relatedly, the Federal Reserve has taken a number of dramatic actions in credit markets and through monetary policy. 
This section gives a brief overview of the most significant provisions and facilities that have been established to assist state governments. This is not intended to be a comprehensive overview, but instead highlights, for each bill, the parts that most significantly increase state revenues. We note that a significant share of these funds will flow directly to households and service providers through joint federal-state programs.

The first piece of Covid-19 related federal legislation was H.R. 6074, the Coronavirus Preparedness and Response Supplemental Appropriations Act. H.R. 6074 was signed into law on March 6. It enacted an $\$ 8.3$ billion package focused heavily on funding the initial public health response to the pandemic. Of these monies $\$ 950$ million was appropriated to states and localities for public health activities. A week after this bill passed, the president declared Covid-19 an emergency under Section 501(b) of the Stafford Act, which, among other things, makes certain federal funds available to state governments in the form of Public Assistance grants (Schaengold, 2020). Earlier, on January 31, the Secretary of Health and Human Services had declared a public health emergency under Section 319 of the Public Health Service Act (42 U.S.C. 247d). ${ }^{12}$

The first bill was followed less than two weeks later, on March 18, by H.R. 6201, the Families First Coronavirus Response Act. H.R. 6201 provides \$1 billion in emergency grants to the states' Unemployment Trust Fund accounts, as well as interest-free loans to assist the states in funding unemployment benefits. It also provides full federal funding of extended unemployment insurance benefits, rather than the usual $50 \%$, at an estimated cost of $\$ 3.7$ billion in the current calendar year. More significant federal funds are linked to H.R. 6201's health care provisions. A key provision increases the federal matching assistance percentage (FMAP) for the bulk of states' Medicaid expenditures by 6.2

\footnotetext{
12 In principle, this declaration creates authority for dispensing public health resources through many channels, including through the Medicare and Medicaid programs. Included among these channels is the Public Health Emergency Fund, which has, perhaps unfortunately, maintained a zero balance since at least the year 2012 (Katz et al., 2017; Alton and Carlin, 2020).
} 
percentage points for the duration of the public health crisis. The CBO estimates that this provision will cost the federal government $\$ 50$ billion from 2020 through 2022 (Congressional Budget Office, 2020c).

The third bill passed by Congress in response to the crisis was, at the time of writing, the largest yet. H.R. 748, the Coronavirus Aid, Relief, and Economic Security (CARES) Act, became law on March 27. H.R. 748 dramatically expanded unemployment insurance benefits through a supplemental, federally funded, $\$ 600$ weekly benefit. The bill also funded and expanded benefits for certain categories of selfemployed workers who are not usually eligible for unemployment insurance. Further, H.R. 748 creates a $\$ 150$ billion Coronavirus Relief Fund, $\$ 110$ billion of which is earmarked for the reimbursement of state government expenses related to the pandemic. It also appropriates $\$ 100$ billion in supplemental reimbursements for hospitals and other health care providers through the Public Health and Social Service Emergency Fund. A significant share of these costs would otherwise have been borne by state governments. The Senate Appropriations Committee has identified a further $\$ 174$ billion in funds appropriated in the Cares Act that will flow, in its words, "to state and local governments and communities" (Senate Appropriations Committee, 2020). It is arguable and not obvious, however, how much of this $\$ 174$ billion constitutes additional revenue for state governments and how much of it can replace lost revenue. Significant elements of this $\$ 174$ billion aggregate include $\$ 45$ billion for the FEMA Disaster Relief Fund, $\$ 30.9$ billion for the Education Stabilization Fund, and $\$ 25$ billion for transit infrastructure grants.

Finally, the Cares Act appropriates $\$ 454$ billion for the Treasury Department to backstop lending facilities operated by the Federal Reserve. For state governments, the most important lending facility is the Municipal Liquidity Facility. This facility will purchase up to $\$ 500$ billion of short-term notes directly from U.S. states, counties, and cities (Board of Governors of the Federal Reserve System, 2020). 
Less than a month after the Cares Act passed, Congress decided it had not appropriated sufficient funds for certain elements of the federal crisis response. H.R. 266, the Paycheck Protection Program and Health Care Enhancement Act, became law on April 24. It adds $\$ 75$ billion to the Public Health and Social Service Emergency Fund. It also provides \$11 billion for states and localities to develop so-called "test and trace" programs.

At the time of writing, additional funding for state and local governments, especially funding to make up for revenue shortfalls as opposed to new Covid-19 related spending, had become a topic of heated political debate. The Democratic Party-controlled House of Representatives passed H.R. 6800, the Heroes Act, on May 15. H.R. 6800 would provide over \$1 trillion to state and local governments, including $\$ 915$ billion in flexible funds that can be used to make up for revenue losses. Such an amount would far exceed our estimates of the income and sales tax revenue lost in fiscal years 2020 and 2021, which sum to just under $\$ 150$ billion ( $\$ 42$ billion for the second quarter of 2020 and $\$ 106$ billion for the subsequent four quarters). As discussed above, however, the shortfalls we estimate are clearly not the only revenue losses to consider. The Senate, controlled by a Republican majority, appears to be skeptical of legislation on this scale. This skepticism has been rhetorically connected to concerns about states' unfunded pension liabilities.

\section{DISCUSSION}

We conclude by discussing the roles of the local, state, and federal levels of government in the American system of fiscal federalism. State and local governments play substantial roles in the administration and financing of a rich set of public services. These services span education, health care, public safety, public utilities, and income support. To deliver these services, state and local governments have employed just under 20 million workers in recent years (Shoag and Veuger, forthcoming). 
In the financing of public services, states' balanced budget requirements are a key feature of the institutional landscape. These requirements often date to the $19^{\text {th }}$ century. While balanced budget requirements can have benefits with regard to fiscal discipline, they render states unable to contribute to counter-cyclical policy during recessions. Indeed, downturn-induced revenue declines confront states with an array of undesirable options. In the current environment, offsetting a $\$ 106$ billion decline in projected sales and income tax revenues can require a painful mix of wage freezes, hiring freezes, and layoffs. Reductions in public employment risk exacerbating the macroeconomic and labor market declines that have already taken place.

In the U.S. institutional environment, the burden of counter-cyclical policy falls on the federal government. In practice, recessionary aid for state and local governments has been enacted on an ad hoc basis. During the financial crisis, this support came primarily through the American Recovery and Reinvestment Act of 2009. In the current crisis, this support has come piecemeal through the legislation discussed above.

We close by noting that the need for ad hoc legislation is a policy choice. This need could largely be avoided by converting existing federal transfers to states, which have exceeded 3\% of GDP in recent years, into grants that adjust counter-cyclically. Possibilities along these lines have been discussed in the context of Medicaid financing reforms (Clemens and Ippolito, 2018; Fiedler, Furman, and Powell, 2020) as well as general intergovernmental support (Bartik, 2020). In each case, the key adjustment is to link federal transfers to states' unemployment rates (or to other measures of macroeconomic well-being). Perennial uncertainties regarding the measurement of unemployment during recessions, which have been heightened during the current pandemic, suggest that broader measures of economic performance might be better suited for this purpose. The risks of Congressional gridlock suggest that reforms of this sort, which blunt the necessity of active fiscal policy, may have substantial benefits. On the other hand, a risk associated with such reforms is that funds will not ultimately be allowed to decline 
during subsequent expansions, such that federal transfers are expected to support state governments at permanently elevated levels. 


\section{REFERENCES}

Alton, Jennifer B., and Ellen P. Carlin, "Now Is the Time to Resource the Public Health Emergency Fund." The Hill, February 28, 2020, https://thehill.com/blogs/congress-blog/healthcare/485163-now-isthe-time-to-resource-the-public-health-emergency-fund.

Anderson, John E., and Shafiun N. Shimul, 2018. "State and Local Property, Income, and Sales Tax Elasticity: Estimates from Dynamic Heterogeneous Panels." National Tax Journal 71(3), 521-546.

Baicker, Katherine, Jeffrey Clemens, and Monica Singhal, 2012. "The Rise of the States: US fiscal Decentralization in the Postwar Period." Journal of Public Economics 96 (11-12), 1079-1091.

Bartik, Timothy J., 2020. "Automatic Stabilizers and Federal Aid to States." Upjohn Institute, Kalamazoo, MI, https://www.upjohn.org/research-highlights/automatic-stabilizers-and-federal-aid-states.

Board of Governors of the Federal Reserve System, 2020. "Municipal Liquidity Facility." Federal Reserve Board of Governors, Washington, DC, https://www.federalreserve.gov/newsevents/pressreleases/files/monetary20200603a1.pdf.

Bruce, Donald, William Fox, and M.H. Tuttle, 2006. "Tax Base Elasticities: A Multi-State Analysis of LongRun and Short-Run Dynamics." Southern Economic Journal 73(2), 315-341.

Bureau of Economic Analysis, 2020. Personal Income and Outlays: April 2020. BEA 20-24. Bureau of Economic Analysis, Washington, DC.

Bureau of Labor Statistics. 2020a. The Employment Situation - May 2020. USDL-20-1140. Bureau of Labor Statistics, Washington, DC.

Bureau of Labor Statistics. 2020b. State Employment and Unemployment - May 2020. USDL-20-1233. Bureau of Labor Statistics, Washington, DC.

Canova, Fabio, 1998. "Detrending and Business Cycle Facts." Journal of Monetary Economics 41(3), 475512.

Clemens, Jeffrey, 2012. "State Fiscal Adjustment During Times of Stress: Possible Causes of the Severity and Composition of Budget Cuts." Manuscript. University of California San Diego, La Jolla, CA.

Clemens, Jeffrey, and Stephen Miran, 2012. "Fiscal Policy Multipliers on Subnational Government Spending." American Economic Journal: Economic Policy 4(2), 46-68.

Clemens, Jeffrey, and Benedic Ippolito, 2018. "Implications of Medicaid Financing Reform for State Government Budgets." Tax Policy and the Economy 32(1), 135-172.

Congressional Budget Office, 2007. The Budget and Economic Outlook: Fiscal Years 2007 and 2016. Congressional Budget Office, Washington, DC.

Congressional Budget Office, 2020a. The Budget and Economic Outlook: 2020 to 2030. Congressional Budget Office, Washington, DC. 
Congressional Budget Office, 2020b. Interim Economic Projections for 2020 and 2021. Congressional Budget Office, Washington, DC.

Congressional Budget Office, 2020c. "Preliminary Estimate of the Effects of H.R. 6201, the Families First Coronavirus Response Act." Letter to Nita M. Lowrey, Chairwoman, Committee on Appropriations, U.S. House of Representatives (April 2). Congressional Budget Office, Washington, DC, https://www.cbo.gov/system/files/2020-04/HR6201.pdf.

Department of Budget and Finance, State of Hawaii, 2020. State Fiscal Reserves. Hawaii Department of Budget and Finance, Honolulu, HI, https://budget.hawaii.gov/budget/about-budget/state-fiscalreserves/.

Driessen, Grant A., 2020. "State and Local Government Debt and COVID-19." CRS in Focus. Congressional Research Service, Washington, DC.

Dye, Richard F., 2004. "State Revenue Cyclicality." National Tax Journal 57(1), 133-145.

Farrell, James, Daniel Shoag, and Stan Veuger, Forthcoming. "Simulating Public Pension Funding with Realistic Asset Prices." In Healey, Thomas J., and Roger B. Porter (ed.) Gathering Storm: The Risks of State Pension Underfunding. Cambridge, United Kingdom: Cambridge University Press.

Fiedler, Matthew, Jason Furman, and Wilson Powell III, 2020. "Increasing Federal Support for State Medicaid and CHIP Programs in Response to Economic Downturns." Brookings Report. The Brookings Institution, Washington, DC.

Hawkins, Richard, 2000. "Price Elasticities in Consumer Sales Tax Revenue." Public Finance Review 26(2), 171-184.

Kaeding, Nicole, 2017. "Sales Tax Base Broadening: Right-Sizing a State Sales Tax." Fiscal Fact No. 563. The Tax Foundation, Washington, DC.

Katz, Rebecca, Aurelia Attal-Juncqua, and Julie E. Fischer, 2017. "Funding Public Health Emergency Preparedness in the United States." American Journal of Public Health 107(Suppl 2), S148-S152.

Kodrzycki, Yolanda K., 2014. "Smoothing State Tax Revenues Over the Business Cycle: Gauging Fiscal Needs and Opportunities." Working Paper No. 14-11. Federal Reserve Bank of Boston, Boston, MA.

Loughead, Katherine, 2020. "State Individual Income Tax Rates and Brackets for 2020." Fiscal Fact No. 693. The Tax Foundation, Washington, DC.

Lutz, Byron, Raven Molloy, and Hui Shan, 2011. "The Housing Crisis and State and Local Government Tax Revenue: Five Channels." Regional Science and Urban Economics 41, 306-319.

National Association of State Budget Officers, 2019. "The Fiscal Survey of the States: An Update of State Fiscal Conditions." National Association of State Budget Officers, Washington, DC. 
National Center for Health Statistics, 2020. "Excess Deaths Associated with COVID-19." Center for Disease Control and Prevention, Washington, DC, https://www.cdc.gov/nchs/nvss/vsrr/covid19/excess deaths.htm.

National Conference of State Legislatures, 2010. "State Balanced Budget Provisions." NCSL Fiscal Brief, October. National Conference of State Legislatures, Washington, DC.

National Conference of State Legislatures, 2018. "Rainy Day Fund Structures." NCSL Fiscal Policy Brief, November. National Conference of State Legislatures, Washington, DC.

Pew Charitable Trusts, The, 2017. "When to Use State Rainy Day Funds: Withdrawal Policies to Mitigate Volatility and Promote Structurally Balanced Budgets." The Pew Charitable Trusts, Washington, DC.

Poterba, James M. 1994. "State Responses to Fiscal Crises: The Effects of Budgetary Institutions and Politics." Journal of Political Economy 102(4), 799-821.

Reed, Robert W., Cynthia L. Rogers, and Mark Skidmore, 2011. "On Estimating Marginal Tax Rates for U.S. States." National Tax Journal 64(1), 59-84.

Schaengold, Michael J., 2020. "The Impact of Recent Stafford Act and Defense Production Act Declarations on COVID-19 Procurements." The National Law Review, March, https://www.natlawreview.com/article/impact-recent-stafford-act-and-defense-production-actdeclarations-covid-19.

Seegert, Nathan, 2016. "Tax Revenue Volatility." Manuscript. The University of Utah, Salt Lake City, UT.

Senate Appropriations Committee, 2020. "\$340 Billion Surge in Emergency Funding to Combat Coronavirus Outbreak." Senate Appropriations Committee, Washington, DC, https://www.appropriations.senate.gov/imo/media/doc/Coronavirus\%20Supplemental\%20App ropriations\%20Summary FINAL.pdf.

Shoag, Daniel, Cody Tuttle, and Stan Veuger, 2019. "Rules Versus Home Rule-Local Government Responses to Negative Revenue Shocks." National Tax Journal 72(3), 543-574.

Shoag, Daniel, and Stan Veuger, forthcoming. "Which Taxes Pay for Which State and Local Employees?" Mercatus Center COVID-19 Policy Brief. Mercatus Center, Arlington, VA.

Smith, Mitch, Karen Yourish, Sarah Almukhtar, Keith Collins, Danielle Ivory, and Amy Harmon, 2020. "Coronavirus (Covid-19) Data in the United States." The New York Times, New York, NY, https://github.com/nytimes/covid-19-data.

Tax Policy Center, 2018. "What Are State Rainy Day Funds, And How Do They Work?” In Briefing Book: A Citizen's Guide to the Fascinating (Though Often Too Complex) Elements of the US Tax System. Tax Policy Center, Washington, DC. 
United States Census Bureau, 2019. 2017 State and Local Government Finance Historical Datasets and Tables. United States Census Bureau, Washington, DC, https://www.census.gov/data/datasets/2017/econ/local/public-use-datasets.html.

Walczak, Jared, 2018. "Tax Reform Moves to the States: State Revenue Implications and Reform Opportunities Following Federal Tax Reform." Tax Foundation Report. The Tax Foundation, Washington, DC.

Walczak, Jared, 2019. "2020 State Business Tax Climate Index." Tax Foundation Report. The Tax Foundation, Washington, DC.

Zhao, Bo, 2016. "Saving for a Rainy Day: Estimating the Needed Size of U.S. State Budget Stabilization Funds." Regional Science and Urban Economics 61, 130-152. 
Figure 1: Updates to CBO's Macroeconomic Forecasts: GDP

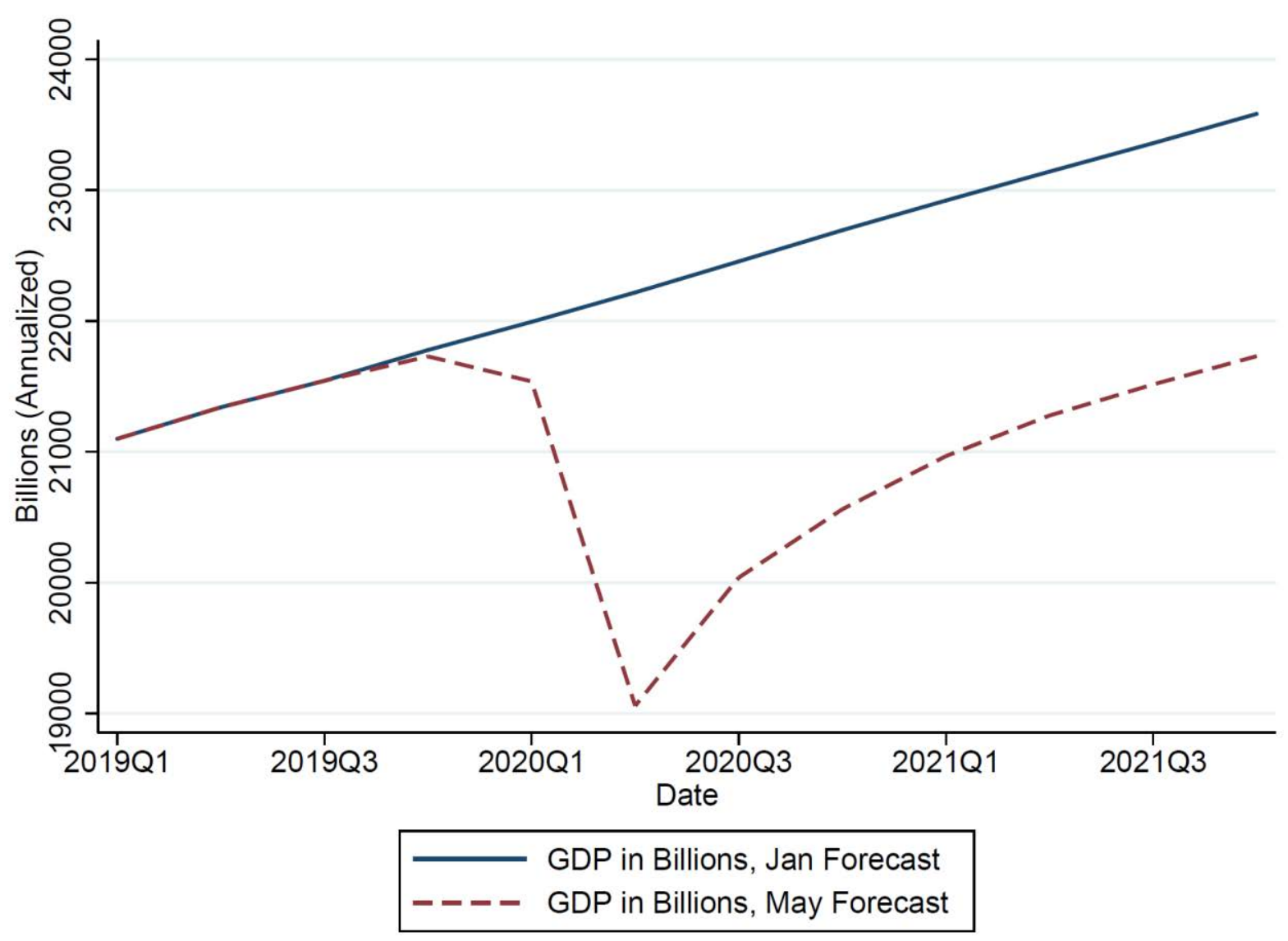

Note: The figure displays data and projections for U.S. GDP. The series labeled "Jan Forecast" comes from the Congressional Budget Office's January 2020 economic outlook (2020a). The series labeled "May Forecast" comes from the Congressional Budget Office's May 2020 economic outlook (2020b). A comparison of the "Jan Forecast" and "May Forecast" series thus reveals the extent to which the Covid-19 pandemic has reduced the Congressional Budget Office's projections for economic activity. 
Figure 2: Updates to CBO's Macroeconomic Forecasts: Income and Consumption

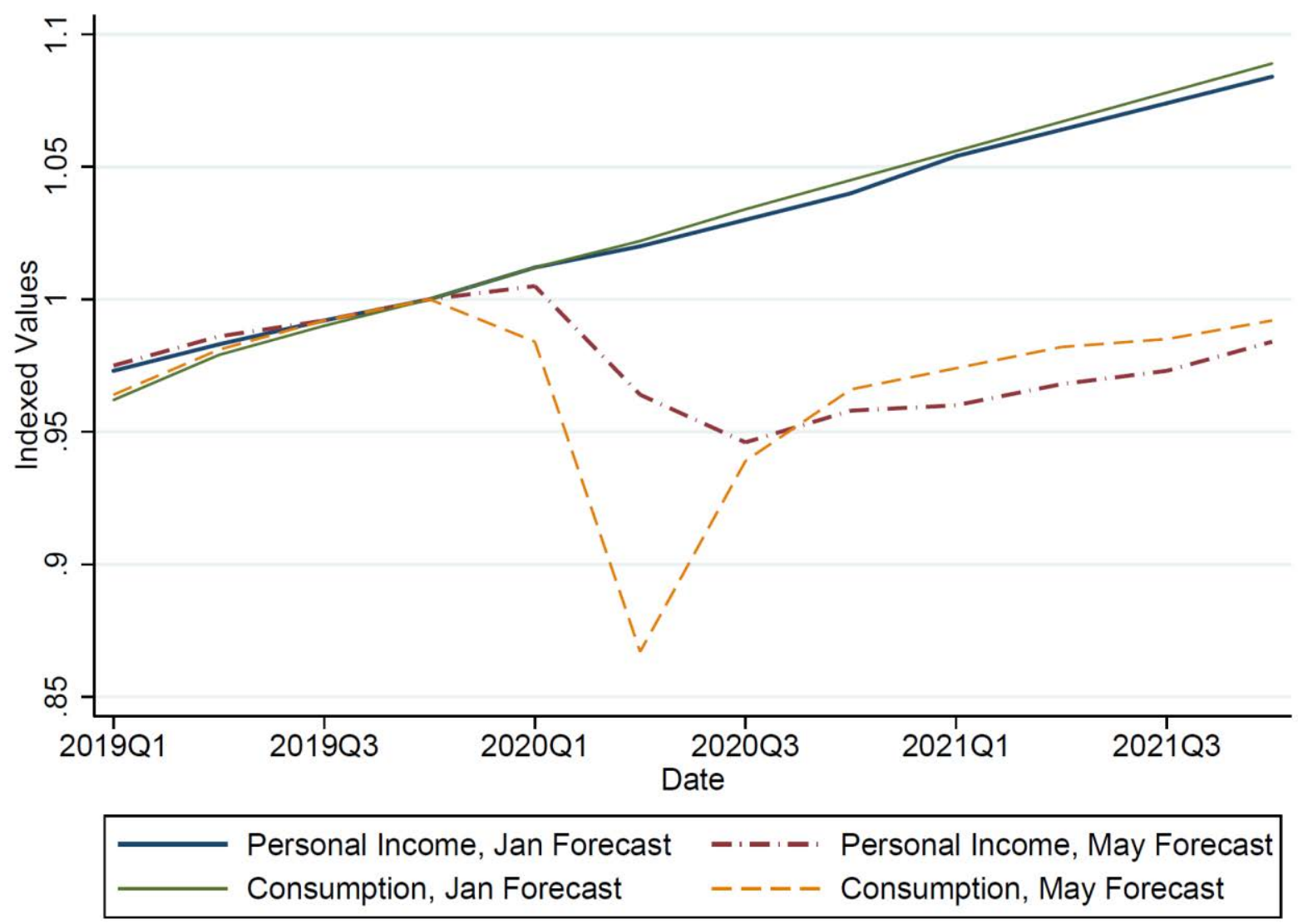

Note: The figure displays straightforward transformations of data and projections for personal income and personal consumption expenditures. The series labeled "Jan Forecast" come from the Congressional Budget Office's January 2020 economic outlook (2020a). The series labeled "May Forecast" come from the Congressional Budget Office's May 2020 economic outlook (2020b). A comparison of the "Jan Forecast" and "May Forecast" series thus reveals the extent to which the Covid-19 pandemic has reduced the Congressional Budget Office's projections for economic activity. Each series is indexed relative to its value from the second quarter of 2008. 
Figure 3: Realizations Relative to CBO Forecast Prior to the Great Recession

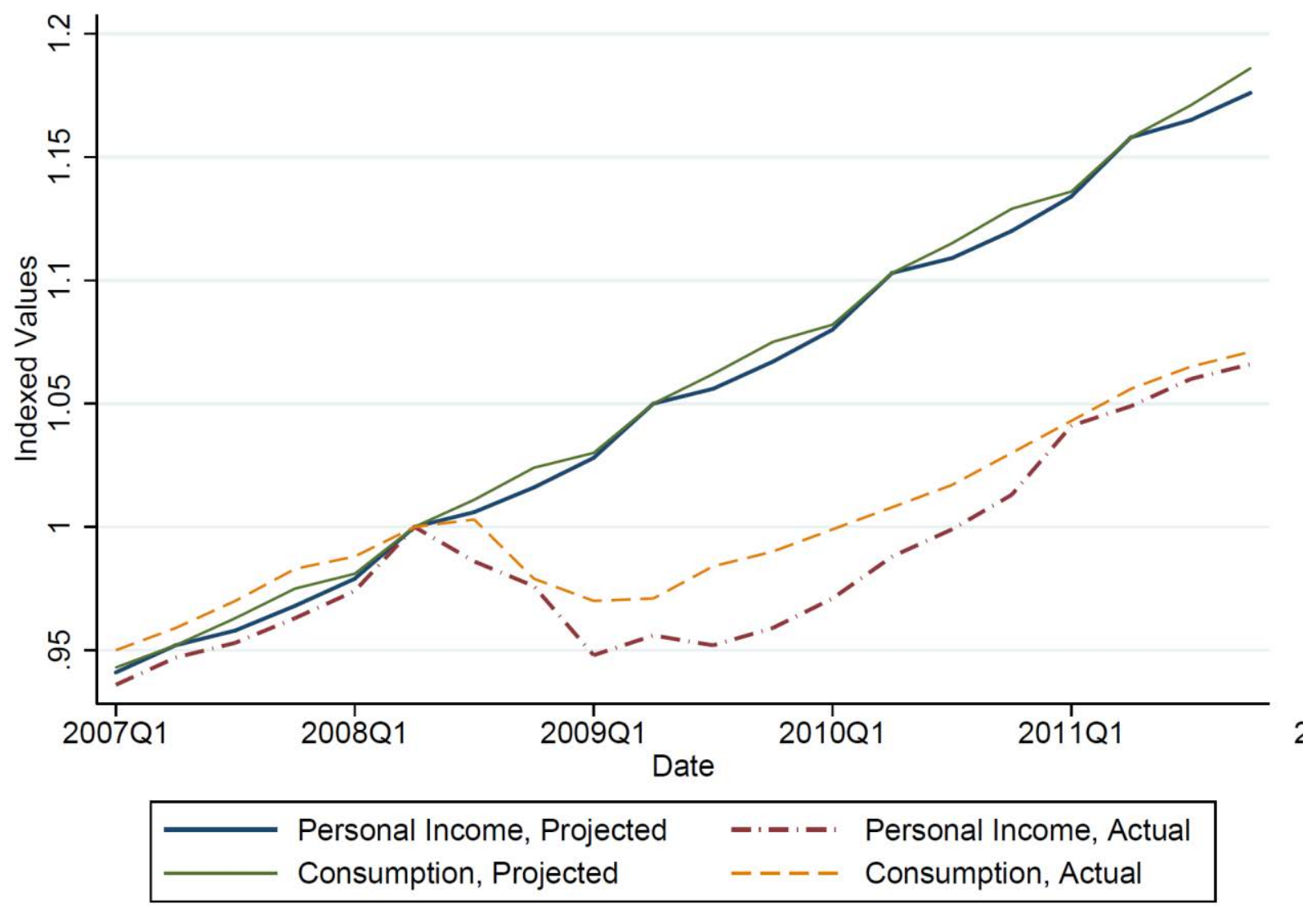

Note: The figure displays straightforward transformations of data and projections for personal income and personal consumption expenditures. The series labeled "Projected" are taken from a 2007 Congressional Budget Office economic outlook (2007). The series labeled "Actual" are from the Bureau of Economic Analysis. A comparison of the "Actual" and "Projected" series thus reveals the extent to which the Great Recession reduced economic activity relative to pre-recession projections. Each series is indexed relative to its value from the second quarter of 2008. 
Figure 4: Projected FY 2020 Sales and Income Tax Exposure

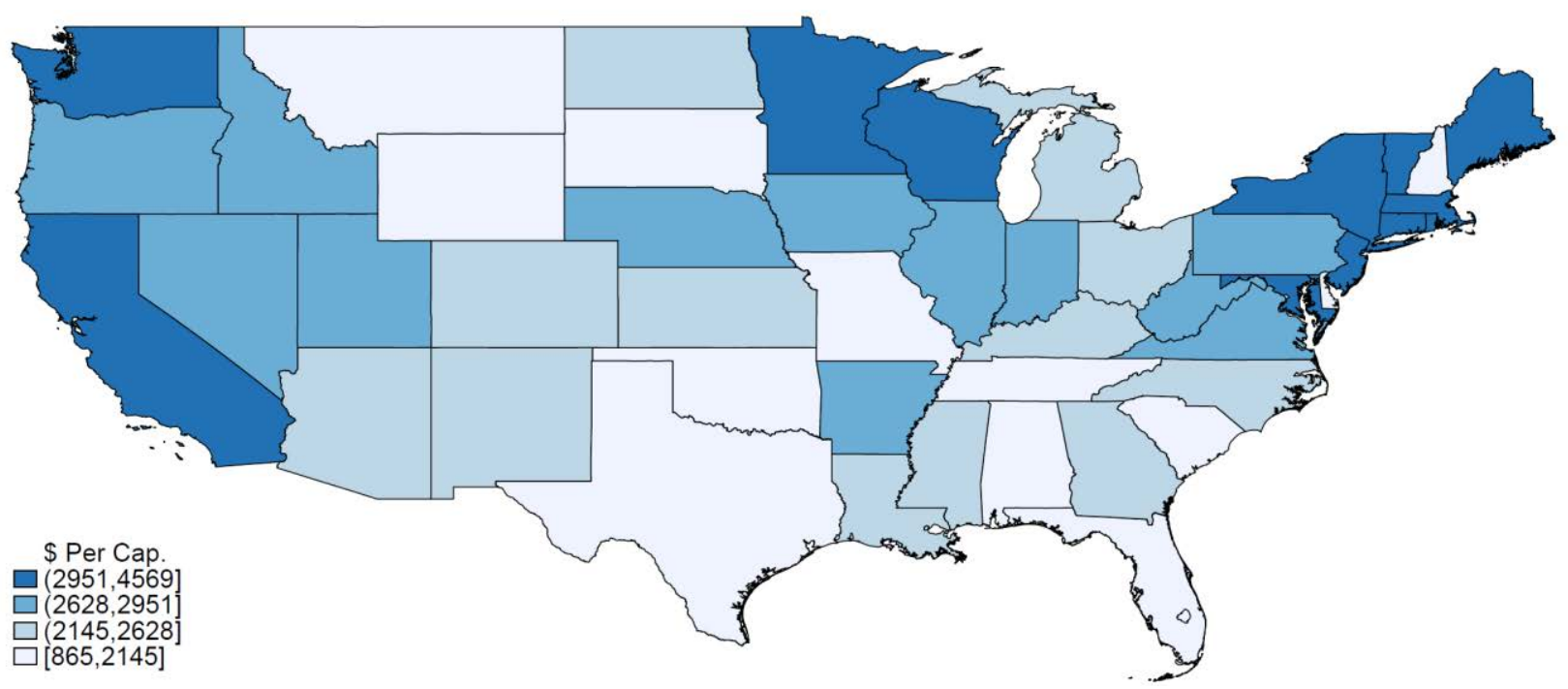

Note: The figure displays data on the sum of state government revenues from "Individual income" and "Sales and gross receipts" taxes, as categorized by the Annual Survey of State and Local Government Finances. The data are taken from the 2017 survey, which was the last year available at the time we conducted our analysis. We account for three years of nominal growth from 2017 to 2020 by multiplying the 2017 values by one plus each state's nominal GDP growth from the fourth quarter of 2016 to the fourth quarter of 2019. The data are presented on a per capita basis. 
Figure 5: Projected FY 2020 Tuition and Fee Exposure

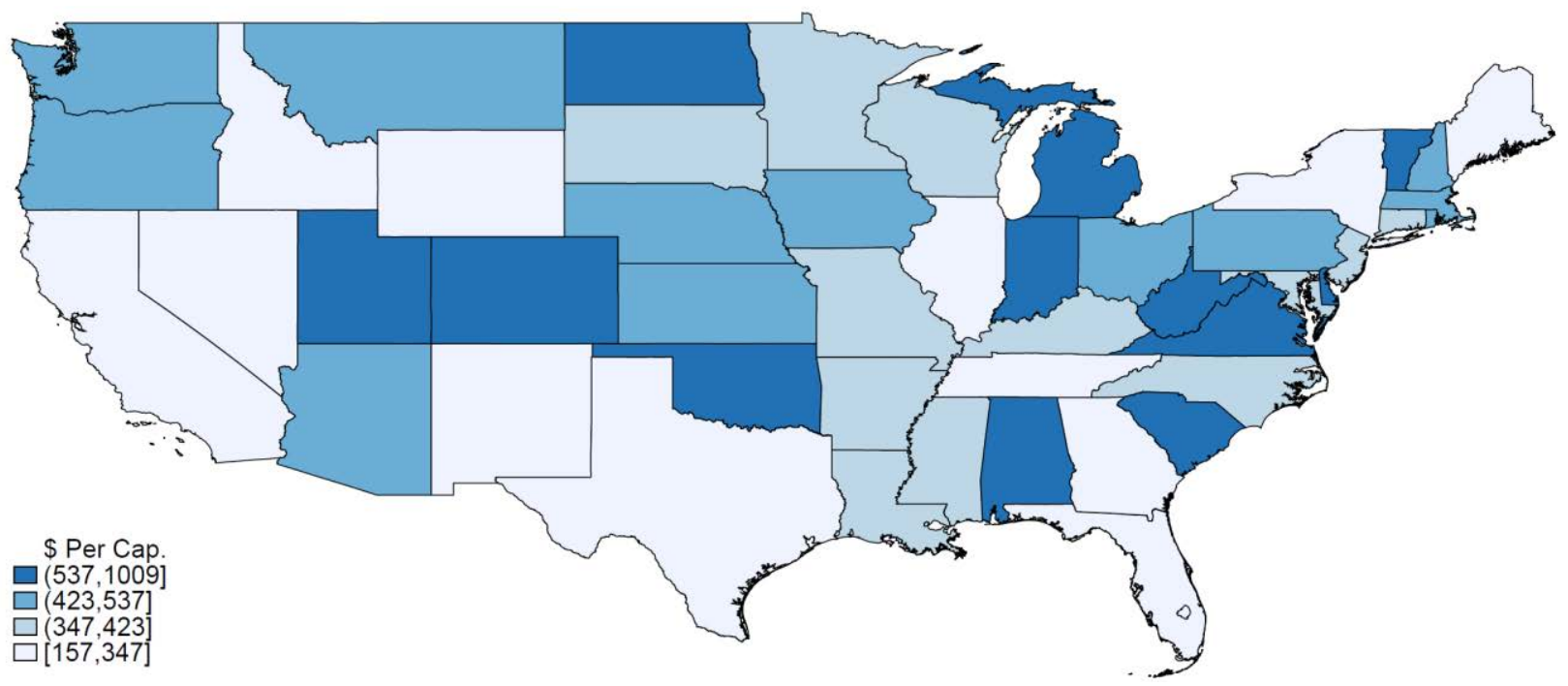

Note: The figure displays data on state government revenue from the Education sub-category of Current Charges, as categorized by the Annual Survey of State and Local Government Finances. The source data are taken from the 2017 survey, which was the last year available at the time we conducted our analysis. We account for three years of nominal growth from 2017 to 2020 by multiplying the 2017 values by one plus each state's nominal GDP growth from the fourth quarter of 2016 to the fourth quarter of 2019. The data are presented on a per capita basis. 


\begin{tabular}{|c|c|c|c|c|c|c|c|}
\hline Panel A: States & $\begin{array}{l}\text { Observations } \\
\text { (1) }\end{array}$ & $\begin{array}{l}\text { Mean } \\
(2)\end{array}$ & $\begin{array}{l}\text { Median } \\
\text { (3) }\end{array}$ & $\begin{array}{c}\text { 10th } \\
\text { Percentile } \\
\text { (4) }\end{array}$ & $\begin{array}{c}\text { 90th } \\
\text { Percentile } \\
\text { (5) }\end{array}$ & $\begin{array}{c}\text { National } \\
\text { Aggregate } \\
\text { (\$ Billions) } \\
(6)\end{array}$ & $\begin{array}{c}\text { Category as } \\
\text { Percent of } \\
\text { National } \\
\text { Total } \\
\text { (7) }\end{array}$ \\
\hline \multicolumn{8}{|c|}{ General Revenue from Own } \\
\hline Resources & & 100.0 & 100.0 & 100.0 & 100.0 & 1317 & 100.0 \\
\hline \multicolumn{7}{|l|}{ Taxes: } & Individual \\
\hline Income Tax & 50 & 22.2 & 22.7 & 0.0 & 38.3 & 351 & 26.7 \\
\hline Sales Tax & 50 & 33.8 & 32.2 & 20.5 & 55.3 & 457 & 34.7 \\
\hline $\begin{array}{l}\text { Property Tax } \\
\text { Corporate }\end{array}$ & 50 & 2.2 & 0.1 & 0.0 & 7.0 & 16 & 1.2 \\
\hline Income Tax & 50 & 3.1 & 2.8 & 0.5 & 4.9 & 45 & 3.4 \\
\hline Other Taxes & 50 & 7.3 & 5.2 & 3.0 & 13.7 & 76 & 5.8 \\
\hline \multicolumn{8}{|l|}{ Charges and } \\
\hline Misc. Revenue & 50 & 31.5 & 29.6 & 21.8 & 41.7 & 371 & 28.2 \\
\hline \multicolumn{8}{|l|}{ Panel B: } \\
\hline \multicolumn{8}{|c|}{ General Revenue from Own } \\
\hline Resources & & 100.0 & 100.0 & 100.0 & 100.0 & 1091 & 100.0 \\
\hline \multicolumn{8}{|l|}{ Taxes: } \\
\hline Income Tax & 50 & 1.8 & 0.0 & 0.0 & 6.5 & 32 & 2.9 \\
\hline Sales Tax & 50 & 10.5 & 8.9 & 0.7 & 22.5 & 123 & 11.3 \\
\hline Property Tax & 50 & 48.4 & 45.9 & 33.0 & 77.0 & 509 & 46.7 \\
\hline \multicolumn{8}{|l|}{ Corporate } \\
\hline Income Tax & 50 & 0.2 & 0.0 & 0.0 & 0.5 & 8 & 0.7 \\
\hline Other Taxes & 50 & 2.9 & 1.9 & 1.1 & 6.4 & 32 & 2.9 \\
\hline \multicolumn{8}{|l|}{ Charges and } \\
\hline Misc. revenue & 50 & 36.2 & 37.4 & 20.6 & 50.6 & 384 & 35.2 \\
\hline
\end{tabular}

Note: This table reports summary statistics for the percentage of tax revenue by source for the 50 US states and their various localities. These data are from the 2017 US Census Annual Survey of State and Local Government Finances. Panel A includes statistics for the 50 US states and Panel B shows statistics for the municipalities, school districts, and other local governments within the 50 states, aggregated up to the state level. Columns 6 and 7 differ from earlier columns in that they present national aggregates rather than data equally weighted across the 50 states. "Sales Tax" refers to the Census Bureau's line item "Sales and gross receipts," which includes both General and Selective sales taxes. Other category names correspond more obviously with their Census Bureau counterparts. Sources: US Census Annual Survey of State and Local Government Finances (2019). 
Table 2: COVID Shocks at the National Level

\begin{tabular}{lcccc}
\hline & $\Delta$ Feb - & $\Delta$ March & $\Delta$ April - & $\Delta$ April '19- \\
& March & - April & May & April '20 \\
& $(1)$ & $(2)$ & $(3)$ & $(4)$ \\
\hline Deaths per 100,000 People & 12.5 & 81.9 & & \\
New Cases per 100,000 People & 57.4 & 270.3 & 220.4 & \\
Employment (\% Change) & -0.1 & -13.7 & 1.9 & -13.3 \\
Unemployment Rate (P.P. Change) & 0.9 & 10.3 & -1.4 & 11.1 \\
Income (\% Change) & -2.2 & 10.5 & & 11.7 \\
Wages and Salaries (\% Change) & -3.5 & -8.0 & & -8.5 \\
Consumption (\% Change) & -6.9 & -13.6 & & -16.9 \\
Goods (\% Change) & -1.6 & -16.5 & & -16.3 \\
$\quad$ Non-Durables Goods (\% Change) & 3.9 & -16.2 & & -11.6 \\
$\quad$ Food off Premises (\% Change) & 22.6 & -15.2 & & 5.6 \\
Durable Goods (\% Change) & -12.1 & -17.3 & & -25.5 \\
Services (\% Change) & -9.3 & -12.2 & & -17.2 \\
$\quad$ Food on premises (\% Change) & -27.4 & -34.6 & & -50.9 \\
Health Care (\% Change) & -16.3 & -28.7 & & -37.8 \\
Other Prof. Services (\% Change) & -3.8 & -4.3 & & -4.1 \\
\hline \hline
\end{tabular}

Notes: This table reports changes in a set of health and macroeconomic proxies for the magnitude of shocks associated with the COVID-19 pandemic. Column 1 reports changes from February 2020 to March 2020, column 2 reports changes from March 2020 to April 2020, column 3 reports changes from April 2020 to May 2020, and column 4 reports changes from April 2019 to April 2020. Excess deaths per 100,000 people are deaths above predicted trends, as calculated by the Center for Disease Control. New COVID cases per 100,000 people are new reported cases for each month from the New York Times' "Coronavirus Data in the United States," accessed through GitHub, and reported on a per 100,000 persons basis. Employment refers to total non-farm employment, as reported by the Bureau of Labor Statistics. The unemployment rate is also taken from the Bureau of Labor Statistics. All data on changes in income, wages and salaries, and consumption come from the National Income and Product Accounts compiled by the Bureau of Economic Analysis. Note that the unemployment rate is the only economic series for which we present changes in percentage point terms rather than percentage terms.

Sources: National Center for Health Statistics, 2020; Smith et al (2020); Bureau of Labor Statistics (2020a); Bureau of Economic Analysis (2020). 
Table 3: Estimated Shortfalls in State Sales and Income Tax Revenues Aggregated across All States

\begin{tabular}{|c|c|c|c|c|c|}
\hline Panel A: Calculation Inputs & $\begin{array}{c}\text { Actual } 2017 \\
\text { Revenues } \\
\text { (\$ Billions) } \\
\text { (1) }\end{array}$ & $\begin{array}{c}\text { Counterfactual } \\
2020 \text { Revenues } \\
\text { (\$ Billions) } \\
\text { (2) }\end{array}$ & $\begin{array}{c}\text { Tax Base } \\
\text { Shock for } \\
\text { Q2 } 2020 \\
\text { (3) }\end{array}$ & $\begin{array}{c}\text { Tax Base } \\
\text { Shock for } \\
\text { Q3 2020-Q2 } \\
2021 \\
\text { (4) }\end{array}$ & $\begin{array}{c}\text { Assumed } \\
\text { Elasticity } \\
\text { (5) }\end{array}$ \\
\hline Individual Income Tax & 352 & 400 & $-0.119 *$ & -0.089 & 1.6 \\
\hline \multirow[t]{2}{*}{ Sales Tax } & 457 & 525 & -0.155 & -0.085 & 1.1 \\
\hline & $\begin{array}{l}\text { Aggregate } \\
\text { Projected } \\
\text { Revenue } \\
\text { Shortfall for } \\
\text { Q2 2020 } \\
\text { (\$ Billions) }\end{array}$ & $\begin{array}{c}\text { Aggregate } \\
\text { Projected } \\
\text { Revenue } \\
\text { Shortfall for Q3 } \\
\text { 2020-Q2 2021 } \\
\text { (\$ Billions) }\end{array}$ & & & \\
\hline Panel B: Estimated Shortfalls & $(1)$ & $(2)$ & & & \\
\hline Individual Income Tax & -19 & -57 & & & \\
\hline Sales Tax & -23 & -49 & & & \\
\hline
\end{tabular}

Note: The entries in column 1 of Panel A were taken directly from the 2017 US Census Annual Survey of State and Local Government Finances. The entries in column 2 of Panel A accounts for three years of nominal revenue growth from 2017 to 2020 . We do this by taking each state's sales and income tax revenues from 2017 and projecting them forward by multiplying by one plus each state's nominal GDP growth from the fourth quarter of 2016 to the fourth quarter of 2019. We then add the projected state sales and income tax revenues together to arrive at the projected national totals reported in the table. The entries in column 3 and 4 of Panel A were calculated using forecasts of personal income and personal consumption expenditures in Congressional Budget Office reports from January 2020 and May 2020; the relevant series are also reported in Figure 2. The entries in column 5 of Panel A are tax revenue elasticities that are estimated based on a combination of existing research and contemporary knowledge of state tax bases and the Covid-19 pandemic. The entries in Panel B are computations made using the entries in Panel A. The entries in column 1 of Panel B are the product of columns 2, 3, and 5 of the corresponding rows in Panel A, which are then multiplied by 0.25 to account for the fact that the estimates correspond with a single quarter out of the fiscal year. The entries in column 2 of Panel B are the product of the entries in columns 2, 4, and 5 of the corresponding rows in Panel A. Note that the estimated shortfalls will move proportionately with the assumed elasticities. Our assumed elasticities draw most directly on estimates from Holcombe and Sobel (1997), Kodrzycki (2014), and Anderson and Shimul (2018).

* Note that the tax base shock for Q2 2020 accounts for the fact that CBO's projection of personal income includes $\$ 300$ billion ( $\$ 1,200$ billion annualized) in Economic Impact Payments through the CARES Act. Because these payments will not be considered taxable income, we subtract them from aggregate personal income to obtain our estimate of the income tax base. We thus estimate that the income tax base declines by $11.9 \%$ while personal income per se declines by $5.6 \%$.

Sources: US Census Annual Survey of State and Local Government Finances (2019); Congressional Budget Office (2020a,b). 
Table 4: Distribution of Expected Sales and Income Tax Shortfalls (\$ Per Capita)

\begin{tabular}{|c|c|c|c|c|c|}
\hline Panel A: Last Quarter of Fiscal Year 2020 & $\begin{array}{c}\text { Observations } \\
\text { (1) }\end{array}$ & $\begin{array}{c}\text { Mean } \\
\text { (2) }\end{array}$ & $\begin{array}{c}\text { Median } \\
\text { (3) }\end{array}$ & $\begin{array}{c}\text { 10th } \\
\text { Percentile } \\
(4)\end{array}$ & $\begin{array}{c}\text { 90th } \\
\text { Percentile } \\
\text { (5) }\end{array}$ \\
\hline \multicolumn{6}{|l|}{ Taxes: } \\
\hline Sales Tax & 50 & 67 & 69 & 37 & 88 \\
\hline Individual Income Tax & 50 & 52 & 53 & 0 & 108 \\
\hline Combined Sales and Income Tax & 50 & 119 & 117 & 81 & 182 \\
\hline Panel B: Fiscal Year 2021 & (1) & $(2)$ & (3) & (4) & (5) \\
\hline \multicolumn{6}{|l|}{ Taxes: } \\
\hline Sales tax & 50 & 147 & 151 & 81 & 193 \\
\hline Individual Income Tax & 50 & 156 & 160 & 0 & 325 \\
\hline Combined Sales and Income Tax & 50 & 303 & 297 & 177 & 496 \\
\hline Panel C: Counterfactual Revenue Projection & $(1)$ & $(2)$ & (3) & $(4)$ & (5) \\
\hline \multicolumn{6}{|l|}{ Taxes: } \\
\hline Sales tax & 50 & 1,572 & 1,612 & 862 & 2,069 \\
\hline Individual Income Tax & 50 & 1,094 & 1,121 & 0 & 2,279 \\
\hline Combined Sales and Income Tax & 50 & 2,666 & 2,628 & 1,893 & 3,986 \\
\hline Fees and Miscellaneous Revenue & 50 & 1,937 & 1,621 & 1,120 & 3,160 \\
\hline Higher Education Revenue & 50 & 438 & 415 & 277 & 621 \\
\hline
\end{tabular}

Note: This table reports summary statistics from calculations of projected revenue shortfalls for each of the 50 US states on a per capita basis. The shortfalls are calculated as follows:

Revenue Shortfall $_{i, b}=$ Counterfactual Revenue $_{i, b} \times$ Base Decline $_{b} \times$ Revenue Elasticity $_{b}$

In the expression above, Revenue Shortfall ${ }_{i, b}$ is the calculated per capita revenue shortfall for state " $i$ " from tax base " $b$. ." In Panel A, the presented shortfalls correspond to estimates for the second quarter of 2020, which is the last quarter of most states' 2020 fiscal years. In Panel B, the presented shortfalls correspond to estimates for the third quarter of 2020 through the second quarter of 2021, which corresponds to the entirety of most states' 2021 fiscal years. For various revenues bases, Panel $C$ presents our estimates of Counterfactual Revenue $_{i, b}$ which is the estimated revenue for state " $i$ " from tax base " $b$ " in the absence of the COVID-19 pandemic. We obtain these estimates by straightforwardly multiplying 2017 revenue collections (as reported in the Census Bureau's 2017 Survey of State and Local Government Finances) by one plus each state's nominal GDP growth from the fourth quarter of 2016 to the fourth quarter of 2019. This accounts for three years of nominal revenue growth from 2017 to 2020. The Base Decline B $_{b}$ term corresponds to our estimate of the Covid 19-induced shortfall in either the income or sales tax base, expressed in percent terms. The calculation of the relevant values of Base Decline ${ }_{b}$ is further described in the main text and in the note to Table 3 . The estimates of Base Decline Bare driven by CBO's forecasts for our proxies for the income and sales tax bases. As noted previously, our projection of the income tax base for the second quarter of 2020 excludes the Economic Impact Payments enacted through the March 2020 CARES Act because these payments are not taxable at the federal level. Finally, Revenue Elasticity ${ }_{b}$ is an estimate of the elasticity of revenues with respect to size of the tax base. For sales taxes we use an elasticity of 1.1 and for income taxes we use an elasticity of 1.6, both of which are motivated by the literature. Note that the estimated shortfalls will move proportionately with the assumed elasticities. Our assumed elasticities draw most directly on estimates from Holcombe and Sobel (1997), Kodrzycki (2014), and Anderson and Shimul (2018).

Sources: US Census Annual Survey of State and Local Government Finances (2019); Congressional Budget Office (2020a,b). 
Table 5: State Rainy Day Funds in FY 2019 and FY 2020

\begin{tabular}{|c|c|c|c|c|c|}
\hline \multirow[b]{2}{*}{ State } & \multirow[b]{2}{*}{$\begin{array}{c}\text { FY Start } \\
(1)\end{array}$} & \multicolumn{2}{|c|}{ FY 2019 (Preliminary) } & \multicolumn{2}{|c|}{ FY 2020 (Enacted) } \\
\hline & & $\begin{array}{c}\text { Rainy Day Funds } \\
\text { (\$ Millions) } \\
(2)\end{array}$ & $\begin{array}{l}\text { Rainy Day } \\
\text { Funds/ } \\
\text { Expenditures } \\
\text { (3) }\end{array}$ & $\begin{array}{c}\text { Rainy Day Funds } \\
\text { (\$ Millions) } \\
\text { (4) }\end{array}$ & $\begin{array}{l}\text { Rainy Day } \\
\text { Funds/ } \\
\text { Expenditures } \\
\text { (5) }\end{array}$ \\
\hline California & July 1 & 20,646 & 14.5 & 19,204 & 13.0 \\
\hline New York & April 1 & 2,048 & 2.8 & 2,476 & 3.2 \\
\hline Texas & September 1 & 10,089 & 19.3 & 7,830 & 12.9 \\
\hline Florida & April 1 & 1,483 & 4.4 & 1,574 & 4.6 \\
\hline Pennsylvania & July 1 & 23 & 0.1 & 340 & 1.0 \\
\hline Ohio & July 1 & 2,692 & 8.0 & 2,692 & 7.7 \\
\hline Illinois & July 1 & 4 & 0.0 & 4 & 0.0 \\
\hline New Jersey & July 1 & 401 & 1.1 & 401 & 1.0 \\
\hline Michigan & October 1 & 1,149 & 11.0 & & \\
\hline North Carolina & July 1 & 1,254 & 5.3 & & \\
\hline Washington & July 1 & 1,671 & 7.3 & 1,948 & 8.0 \\
\hline US Median & & & 7.6 & & 8.0 \\
\hline
\end{tabular}

Note: This table shows balances of rainy-day funds for selected states (the largest ten by revenue, plus Washington) in fiscal years 2019 and 2020. Column 1 reports the start of the fiscal year in each state. Column 2 and column 3 report the total balance of rainy-day funds for each state in millions of nominal US dollars and the rainy-day fund balance as a percentage of state expenditures for FY 2019. Columns 4 and 5 report the total balance of rainy-day funds and rainy-day funds as a percentage of state expenditures for FY 2020. Values for FY 2019 are preliminary numbers reported in the fall of 2019. FY 2020 numbers are from enacted budgets.

Sources: National Association of State Budget Officers (2019). 